\title{
A novel Tetracyclic Sesquiterpene from the Genus Hortonia
}

\author{
Rukmal Ratnayake ${ }^{1, *}$ and Nimesha Wickramaratne ${ }^{2}$ \\ ${ }^{I}$ Department of Chemistry, Faculty of Natural Sciences, Open University, Polgolla, Sri Lanka \\ ${ }^{2}$ Department of Chemistry, University of Peradeniya, Sri Lanka
}

Received: 30/05/2017; Accepted: 07/08/2017

\begin{abstract}
A new tetracyclic sesquiterpene, 1, 5, 12 trimethyltetracyclic $\left[6,3,0,0,0^{3,4,8}\right]$ dodecane was isolated from the dichloromethane extract of Hortonia angustifolia. It was characterized by means of Mass and NMR spectroscopic analysis. It was found to be biologically inactive in the mosquitolarvicidal assay and moderately active against the fungus Cladosporium cladosprioides.
\end{abstract}

Keywords: Hortonia agnustifolia, endemic plant, dichloromethane extract novel tetracyclic sesquiterpene.

\section{INTRODUCTION}

Sri Lanka is a biodiversity hot spot with $25 \%$ of its flowering plants being endemic. The diversity of Sri Lankan flora in comparison to peninsular India has led to speculation that during the continental drift, Sri Lanka may have experienced a higher degree of impoverishment, which would have contributed to the facilitation of speciation of new taxa. Among the lower plants such as lichens, the recent reports of new species being discovered frequently indicate that their diversity may be as high as the higher plants (Orange et al., 2001). Sri Lankan plants have been tested for biological activity with promising results (Hewage et al., 1998). In addition, the structural diversity among Sri Lankan higher and lower plants are typified by the discovery of, alkaloids, (Puvenendran et al., 2008), compounds with iron chelating function (Sahib et al., 2008; Kathirgmanathar et al., 2006; Karunaratne et al., 1992; Kumar et al., 1989), and phenolic acids and ketones (Kumar et al., 1990), all possessing a variety of bioactivities.

The genus Hortonia is endemic to Sri Lanka and Dassanayake (1996) lists three distinct species ( $H$. floribunda Wight ex Arn., $H$. angustifolia (Thw.) Trimen and $H$. ovalifolia Wight). Some phytogeographers consider the genus Hortonia to have originated in
Gondwanaland about 100-200 million years ago (Jayasekara, 1997). We have previously reported the isolation of several biologically active and unique natural products from the three species of genus Hortonia ( Ratnayake et al., 2001; Ratnayake et al., 2008a; Ratnayake et al., 2008b; Ratnayake et al., 2008c; Carr et al., 2012). As part of our continuing research to find biologically active compounds from this plant, we isolated one tetracyclic sesquiterpene.

\section{MATERIALS AND METHODS}

\section{The plant material}

H. angustifolia was collected from Kanneliya and was identified with the help of voucher specimens at the Department of Botanic Gardens, Peradeniya, Sri Lanka.

Isolation of $1,5,12$ trimethyltetracyclic $[6,3$, $0,0,0^{3,4,8}$ ] dodecane (figure 1 )

The first fraction, which was inactive in the mosquito larvicidal assay, obtained from the MPLC fractionation of $\mathrm{CH}_{2} \mathrm{Cl}_{2}$ extract of leaves of $H$. angustifolia was subjected to flash chromatography with $\mathrm{CH}_{2} \mathrm{Cl}_{2}$-hexane (1:1) as the eluent to yield the tetracyclic sesquiterpene (figure 1) (yield $2.3 \%$ with respect to leaf extract) as a colourless oil. Compound 1 was subjected to the mosquitolarvicidal assay using the $2^{\text {nd }}$ instar larvae of Aedes aegypti (Bandara et al., 2000) and antifungal assay with the fungus Cladosporium cladosporioides using the TLC bioassay technique (Klarman and Sanford, 1968).

\section{RESULTS AND DISCUSSION}

The tetracyclic sesquiterpene $\mathbf{1}$ gave a molecular ion $\left[\mathrm{M}^{+}\right]$at 204.1878 in its HREIMS consistent with the molecular formula $\mathrm{C}_{15} \mathrm{H}_{24}$ requiring four sites of unsaturation. The IR spectrum of compound $\mathbf{1}$ did not show any diagnostic 
stretching frequencies for functional groups including unsaturation. The ${ }^{13} \mathrm{C}$ NMR data obtained for 1 (Table 1) identified resonances that could be assigned to 15 carbon atoms, in agreement with the HRESIMS data. Resonances detected in the APT spectrum indicated the presence of three quaternary carbons $(\delta 43.91$ (C-8), 35.64 (C-1) and 22.44 (C-5)), three methines $(\delta 38.63(\mathrm{C}-12), 22.97(\mathrm{C}-4)$ and 19.81 $(\mathrm{C}-3)$ ), six methylenes $(\delta 39.24(\mathrm{C}-7), 35.83$ (C6), 34.63 (C-2), 33.58 (C-9), 30.83 (C-11) and $23.97(\mathrm{C}-10))$ and three methyl groups $(\delta 20.30$ (C-15), 16.72 (C-14) and 16.58 (C-13)).

Analysis of ${ }^{1} \mathrm{H} /{ }^{13} \mathrm{C} / \mathrm{COSY} / \mathrm{HMBC}$ NMR data (Table 1) of 1 showed two singlets [ $\delta 0.79$, $\mathrm{H}-14,16.72$, C-14, 1.14, H-15, 20.30, C-15 for the methyl groups correlating with quaternary carbons $(\delta 35.64, \mathrm{C}-1,22.44, \mathrm{C}-5)$ and one doublet $[\delta 0.74(J=6.7 \mathrm{~Hz}), \mathrm{H}-13,16.58(\mathrm{C}-13)$ for a secondary methyl group. Two methylene doublets $[\delta 2.09,1 \mathrm{H}, J=11.9 \mathrm{~Hz}, \mathrm{H}-7,1.00,1 \mathrm{H}$, br d, $J=2.8 \mathrm{~d}, \mathrm{H}-7,39.24, \mathrm{C}-7 ; 1.87,1 \mathrm{H}, J$ $=11.9 \mathrm{~Hz}, \mathrm{H}-6,1.16,1 \mathrm{H}$, br d, $J=2.8,35.83$, C6] showed that they are attached to adjacent carbon atoms. One cyclopropyl proton each appeared as multiplets $[\delta 0.47, \mathrm{H}-3,19.81, \mathrm{C}-3$; $0.85, \mathrm{H}-4,22.97, \mathrm{C}-4]$ which indicated that the third carbon in the three-membered ring was quaternary (22.44, C-5). The protons appearing under the multiplets $[\delta 0.97,1.581 \mathrm{H}$ each, $\mathrm{H}-9$, 33.58 , C-9; $1.02,1.321 \mathrm{H}$ each, H-11, 30.83, C$11 ; 1.36,1.52$ (1H each, H-10, 23.97, C-10; $1.51,1.681 \mathrm{H}$ each, $\mathrm{H}-2,34.63, \mathrm{C}-2 ; 1.64,1 \mathrm{H}$, $\mathrm{H}-12,38.63, \mathrm{C}-12)$ were assigned to a methine (C-12) and four methylenes (C-11, 10, 9 and 2).

COSY/HMBC correlations taken together indicated that the spin system extended from $\mathrm{C}$ 13 to C-9, C-7 to C-6 and C-4 to C-2. Since there were no inter-correlations between the above carbon fragments, it was concluded that C-12, C9, C-7, C-4 and C-2 were attached to quaternary carbons (Figure 2) with C-3, C-4 and C-5 forming the cyclopropyl ring. Thus, in order to complete the structure, the remaining two methyl groups (attached to quaternary carbons) were placed at $\mathrm{C}-1$ and $\mathrm{C}-5$. The resulting structure which fitted the data was concluded to be 1,5 , 12-trimethyltetracyclic $[6,3,0,0,03,4,8]$ dodecane (1) (Ratnayake et al., 2008b).

The tetracyclic sesquiterpene was examined for its biological activity using the mosquito larvicidal and antifungal assay. It was found to be inactive (after $48 \mathrm{hrs}$ ) against the $2^{\text {nd }}$ instar larvae of Aedes aegypti at $10 \mathrm{ppm}$. Interestingly, in the antifungal assay 1 showed a moderate activity against Cladosporium cladosporioides in the TLC bioassay technique (Table 2).

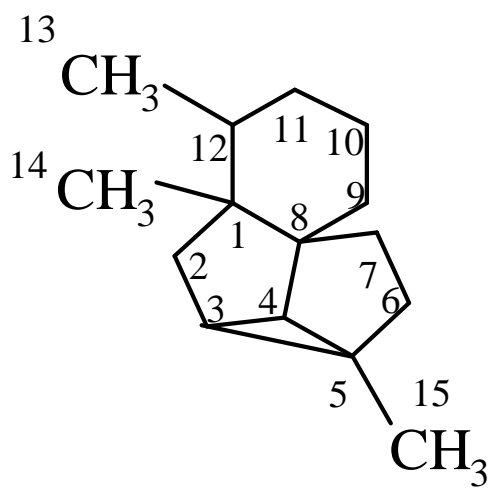

Figure 1: Tetracyclic sesquiterpene, 1, 5, 12 trimethyltetracyclic $\left[6,3,0,0,0^{3,4,8}\right]$ dodecane 
Table 1: 1D and 2D NMR spectroscopic data of compound 1.

\begin{tabular}{|c|c|c|c|c|c|c|}
\hline Carbon & ${ }^{13} \mathrm{C}$ & DEPT & ${ }^{1} \mathbf{H}$ & $\begin{array}{l}\text { multiplicity } \\
(\mathrm{J}, \mathrm{Hz})\end{array}$ & ${ }^{1} \mathbf{H}-{ }^{1} \mathbf{H}$ & HMBC \\
\hline 1 & 35.64 & $\mathrm{C}$ & - & & - & \\
\hline \multirow[t]{2}{*}{2} & \multirow[t]{2}{*}{34.63} & \multirow{2}{*}{$\mathrm{CH}_{2}$} & a 1.51 & \multirow{2}{*}{$\begin{array}{l}\mathrm{m}\left(\mathrm{W}_{1 / 2} 6.15\right) \mathrm{m} \\
\left(\mathrm{W}_{1 / 2} 6.9\right)\end{array}$} & $2 b, 3$ & $1,4,8,14,15$ \\
\hline & & & b 1.68 & & $2 \mathrm{a}, 3$ & $1,3,4,12,14$ \\
\hline 3 & 19.81 & $\mathrm{CH}$ & 0.47 & $\mathrm{~m}$ & $2 a, 2 b, 4$ & \\
\hline 4 & 22.97 & $\mathrm{CH}$ & 0.85 & m (W1/2 12) & 3 & 4,12 \\
\hline 5 & 22.44 & $\mathrm{C}$ & - & & - & - \\
\hline \multirow[t]{2}{*}{6} & \multirow{2}{*}{35.83} & \multirow{2}{*}{$\mathrm{CH}_{2}$} & a 1.16 & brd (2.8) & $6 \mathrm{~b}$ & $4,5,7,15$ \\
\hline & & & b 1.87 & br d (11.9) & $6 a, 7 b$ & $5,6,7,8$ \\
\hline \multirow[t]{2}{*}{7} & \multirow[t]{2}{*}{39.24} & \multirow[t]{2}{*}{$\mathrm{CH}_{2}$} & a 1.0 & br d (2.8) & $7 b$ & 8 \\
\hline & & & b 2.09 & br d (11.9) & $7 \mathrm{a}, 6 \mathrm{~b}$ & $4,6,8$ \\
\hline 8 & 43.91 & $\mathrm{C}$ & - & & - & - \\
\hline \multirow[t]{2}{*}{9} & \multirow[t]{2}{*}{33.58} & \multirow[t]{2}{*}{$\mathrm{CH}_{2}$} & a 0.97 & $\mathrm{~m}\left(\mathrm{~W}_{1 / 2} 5.8\right)$ & $9 \mathrm{~b}$ & \\
\hline & & & b 1.58 & $\mathrm{~m}\left(\mathrm{~W}_{1 / 2} 5.8\right)$ & $9 a, 10 a$ & \\
\hline \multirow[t]{2}{*}{10} & \multirow[t]{2}{*}{23.97} & \multirow[t]{2}{*}{$\mathrm{CH}_{2}$} & a 1.36 & $\mathrm{~m}\left(\mathrm{~W}_{1 / 2} 5.8\right)$ & $9 b$ & 11,12 \\
\hline & & & b 1.52 & $\mathrm{~m}\left(\mathrm{~W}_{1 / 2} 6.15\right)$ & $11 \mathrm{a}$ & $1,7,8,13$ \\
\hline \multirow[t]{2}{*}{11} & \multirow[t]{2}{*}{30.83} & \multirow[t]{2}{*}{$\mathrm{CH}_{2}$} & a 1.02 & $\mathrm{~m}$ & $10 \mathrm{~b}$ & $1,8,9$ \\
\hline & & & b 1.32 & $\mathrm{~m}$ & 12 & \\
\hline 12 & 38.63 & $\mathrm{CH}$ & 1.64 & $\mathrm{~m}\left(\mathrm{~W}_{1 / 2} 6.7\right)$ & $13,11 \mathrm{~b}$ & \\
\hline 13 & 16.58 & $\mathrm{CH}_{3}$ & 0.74 & $\mathrm{~d}(6.7)$ & 12 & 1,12 \\
\hline 14 & 16.72 & $\mathrm{CH}_{3}$ & 0.79 & $\mathrm{~s}$ & - & $1,8,12$ \\
\hline 15 & 20.30 & $\mathrm{CH}_{3}$ & 1.14 & $\mathrm{~s}$ & - & $4,7,15$ \\
\hline
\end{tabular}

Table 2: Antifungal activity of compound 1.

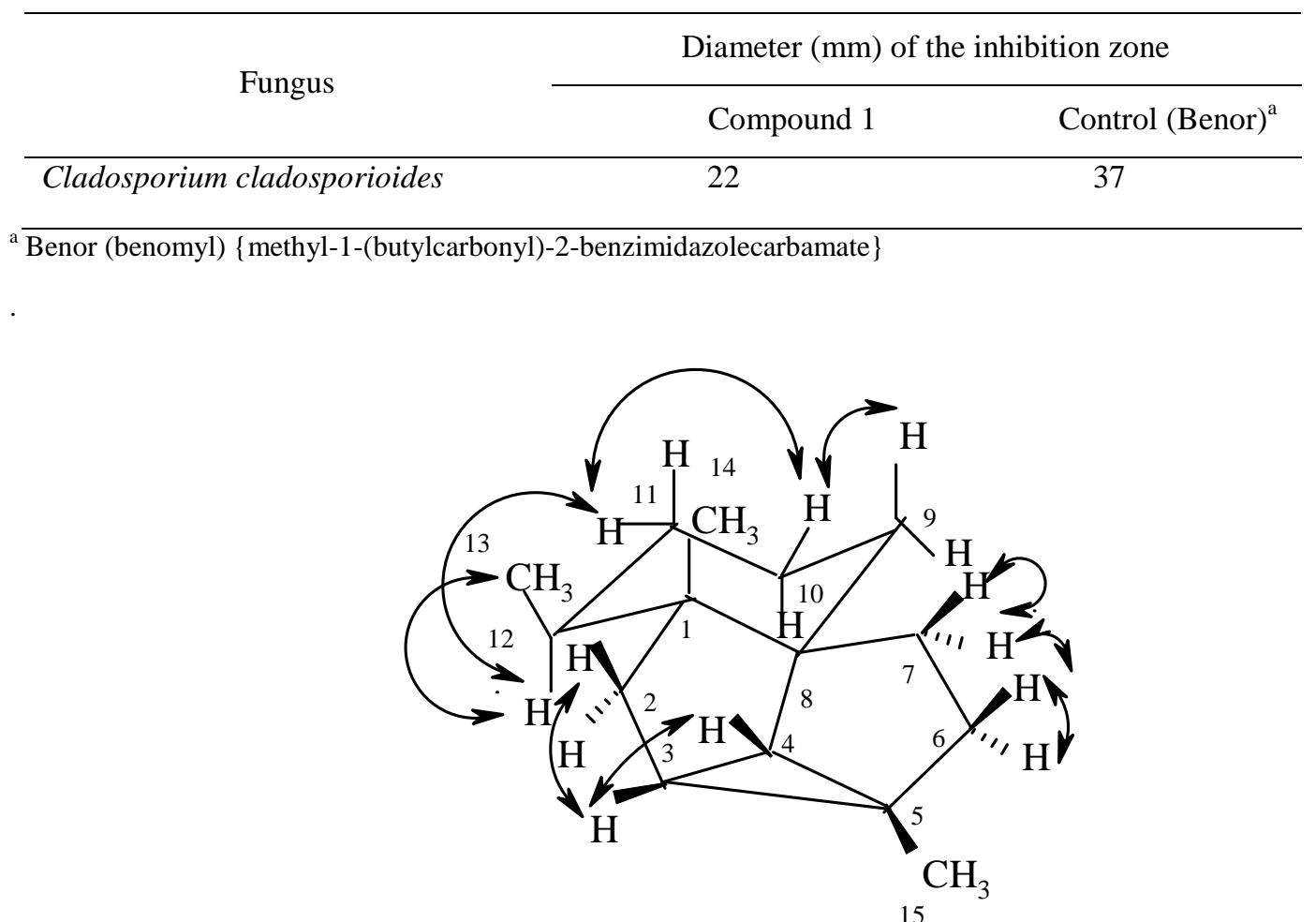

Figure 2: COSY correlations of the compound 1 


\section{ACKNOWLEDGEMENTS}

The authors thank Dr. Siril Wijesundara for helping with the identification of the plant species.

\section{REFERENCES}

Bandara, K. A. N. P., Kumar, V., Jacobson, U. and Molleyres, L. P. (2000). Insecticidal piperine alkaloid from Microscos paniculata stem bark. Phytochemistry 54: 29-32.

Carr, G., Ratnayake, R., Bandara, R., Wijesundara, S., Williams, D.E., Tarling, T., Balgi, A.D., Roberge, M., Karunaratne, V. and Andersen, R.J. (2012). Hydrazulenones from the genus Hortonia. J. of Natural Products 75(6): 1189-1191.

Dassanayake M.D. (1996). A Revised Handbook to the Flora of Ceylon, Volume X; Oxford \& IBH Publishing Co. Pvt. Ltd., New Delhi, pp. 282285.

Hewage, C.M., Bandara, B.M.R., Karunaratne, V., Wannigama, G.P., Pinto, M.R.M. and Wijesundara, D.S.A. (1998). Antibacterial activity of some medicinal plants of Sri Lanka, $J$. National Science Council 26 (1): 27-34.

Jayasekara R. (1997). Arjuna`s Atlas of Sri Lanka. (Eds. T. Somasekaram. M.P. Perera, M.B.G. de Silva \& H. Godellawatte. Arjuna Consulting Co. Ltd., Dehiwala, pp 36.

Klarman, W. L. and Sanford, J. B. (1968). Isolation and purification of an anti-fungal principle from infected soybeans. Life Sciences 7: 1095.

Karunaratne, V., Hoveyda, H.R. and Orvig, C. (1992). General method for the Synthesis of Trishydroxamic acids. Tetrahedron Lett. 33: 1827.

Kathirgamanathar, S., Ratnasooriya, W.D., Baekstrom, P., Andersen, R.J. and Karunaratne, V. (2006). Chemistry and bioactivity of physciaceae lichens: Pyxine consocians and Heterodermia Leucomelos. Pharmaceutical Biology 44: 217-220.

Kumar, V., Karunaratne, V. and Meegalla, M.R.S.K. (1989). 1-[2',4'-Dihydroxy-3',5'-Di(3"Methylbut-2"-Enyl)-6'-Methoxy] Phenylethanone from Acronychia pedunculata root bark. Phytochemistry 28: 1278.

Kumar, V., Karunaratne, V., Meegalla, M.R.S.K. and MacLeod, J.K. (1990). Two fungicidal phenylethanones from Euodia lunu-ankenda root bark. Phytochemistry 29: 243.

Orange, A., Wolseley, P., Karunaratne, V. and Bombuwela, K. (2001). Two Leprarioid Lichens New to Sri Lanka. Bibliotheca Lichenologica 78 : 327-333.

Puvenendran, S., Carr, G., Wickramasinghe, $\quad$ A., Karunaratne, D. N., Andersen, R. J. and Karunaratne, V. (2008). Antioxidant constituents of Xylopia Championii. Pharmaceutical Biology 46: 252-256.

Ratnayake R., Karunaratne V., Ratnayake Bandara B.M., Kumar V., MacLeod J.K. Simmonds P. (2001). Two new lactones with mosquito larvicidal activity from three Hortonia species. $J$. of Natural Products 64: 376- 378.

Ratnayake, R., Bandara, B. M., Wiesundara, D. S. A., Carr, G., Andersen, R.J. and Karunaratne, V. (2008a). Four butanolides derivatives from Hortonia, a genus endemic to Sri Lanka. J. Chemical Research 3: 134-136.

Ratnayake, R., Jayasinghe, S., Andersen, R .J. and Karunaratne, V. (2008b). Complete 2-D assignement and antifungal activity of Ishwarane isolated from the genus Hortonia. $J$. NationalScience Foundation of Sri Lanka 36 (1): 109-122.

Ratnayake, R., Bandara, B.M.R., Wijesundara, D.S.A., MacLeod, J.K., Simmonds, P. and Karunaratne, V. (2008c). Chemistry and bioactivity of the genus Hortonia. Natural Products Research 22: 1393-1402.

Sahib, K., Kularatne, S., Kumar, S. and Karunaratne, V. (2008). The effect of (+)-usnic acid on shothole borer (Xyleborus fornicatus Eichhoff) of tea. Journal of National Science Foundation of Sri Lanka 36 (4): 335-336. 